УДК 766:097](477)”1991

\author{
Петро Володимирович Нестеренко, \\ кандидат мистецтвознавства, доцент, \\ Національна академія \\ образотворчого мистецтва і архітектури, \\ Київ, Україна, \\ e-mail: exlibrisclub@ukr.net, \\ ORCID 0000-0003-4153-4175
}

\title{
ЕКСЛІБРИС ЯК НАРИС ІСТОРЇ̈ КУЛЬТУРИ УКРАЇНИ, КОМПЛЕКСУ ДУХОВНИХ ЗДОБУТКІВ СУСПІЛЬСТВА
}

Анотація. Екслібрис або книжковий знак, виконується художниками для своїх друзів і знайомих, частіше безкоштовно, а також для участі в міжнародних чи місцевих конкурсах, до пам'ятних або ювілейних дат, а також на замовлення, переважно для заможних іноземних колекціонерів. Таким чином, екслібрис є важливим джерелом історії та культури не лише України, а всього людства.

Особливою популярністю користувалась творчість легендарного поета, музиканта i актора Володимира Висоцького, у якого було чимало шанувальників. Вони замовляли екслібриси Миколі Бондаренку з Сумської області, Оресту Криворучку з Чернівців, Миколі Неймешу та Олексію Литвинову з Харкова. Останній на початку 1990-х рр. створив для Вадима Альбертіна 3 Очакова 2 десятки екслібрисів 3 образом В. Висоцького та героїв його творів. Не менш популярною в мистецтві екслібриса був образ Анни Ахматової. Ïї поетичні рядки приваблювали мільйони людей протягом останніх десятиліть, як у нашій країні, так і за кордоном.

Автор понад тисячі екслібрисів, Давид Беккер з Одеси художник широкого тематичного діапазону. Його творчість 
презентована портретними образами відомих композиторів i серією «Карнавали Венеції».

Не менш цікаві кольорові екслібриси Аркадія і Геннадія (батька й сина) Пугачевських, Володимира Вишняка з Києва, Василя Леоненка з Чернігова та ін.

Майстри книжкового знаку полюбляють вшановувати видатних діячів культури і мистецтва минулого й присвячувати їм екслібриси пам'яті. Чимало таких графічних мініатюр створили Георгій Сергєєв з Києва, Борис Дроботюк зі Львова, Іван Балан з Чернівців та інші.

Екслібриси Заслуженого художника України Іван Крислача зі Львова присвячені солістам Львівської національної опери ім. С. Крушельницької та акторам Львівського театру ім. М. Заньковецької. Він також $\epsilon$ автором численних книжкових знаків для львівських музеїв.

Ключові слова: екслібрис, художник, конкурси, ювілейні дати, культура, театр, музей, колекціонери, поети, музиканти, композитори, актори

Вступ. У галузі «духовного виробництва» радянської України переважали важкі парадні форми, присвячені високоідейним темам, - ораторії, опери, врочисті полотна, скульптури, піднесено-патріотичні поеми, музику виконували тпри урочистих нагодах. Паралельно у суспільстві розвивалося книжкова культура, формувалися приватні бібліотечні зібрання. Завзяті книголюби мали власні екслібриси, які підкреслювали особливу любов до джерел знань. Ними вшановували й окремі розділи зібрань, які засвідчували взаємний інтерес художника й власника бібліотеки до вітчизняної та світової культури.

Постановка проблеми. У статті зібрано, систематизовано i всебічно розглянуто роботи провідних художників мистецтва книжкового знаку, які працювали у цьому жанру протягом багатьох років. Виявлено основні концепції, композиційні та образно-стилістичні рішення. 
Окреслено місце екслібрисного надбання в мистецькій спадщині України.

Екслібрис або книжковий знак виконується художниками для своїх друзів і знайомих, частіше безкоштовно, а також для участі в міжнародних чи місцевих конкурсах, до пам'ятних або ювілейних дат, а також на замовлення, переважно заможних іноземних колекціонерів. Він завжди адресований певній людині, яку художник поважає, втілює образно чи символічно глибокий зміст. Кожна графічна мініатюра передає не тільки систему вмінь і навичок, а й систему цінностей. Таким чином, екслібрис є важливим джерелом історії і культури не лише України, а всього людства. Отже, духовна культура українського суспільства висвітлюється завдяки мистецтву книжкового знаку як сегмент світового культурного процесу.

Аналіз останніх досліджень і публікацій. Значні зібрання екслібрисів знаходяться у колекціонерів, а також у музейних та бібліотечних фондах. Держава ще не зацікавлена в цьому виді мистецтва (та й інших теж), у поповнені фондів, тому установи збагачують їх за рахунок пожертвувань колекціонерів. Прикладом цього може бути щедрий подарунок у 2014 р. Степана Давимуки Львівській національній науковій бібліотеці України ім. В. Стефаника - унікальної колекції книжкових знаків, яка налічує 12342 твори малої графіки. Колекція науковця й народного депутата Верховної Ради України у 2005 р. IV скликання, згодом V i VI скликань, формувалася упродовж 50 років (1964-2014 рp.) у тісній співпраці з художниками та колекціонерами того часу. В ній переважають твори українських художників, які яскраво демонструють історію розвитку українського книжкового знаку впродовж десятиліть. Два десятки художників представлені у колекції сотнею й більше екслібрисів [4]. На щастя, подаровані меценатом твори не спіткала доля багатьох інших подібних зібрань, які покинули одне й переселилися в інше закрите для всіх приміщення. Їм була уготована краща доля - за підтримки 
11 небайдужих людей були видані в 2017 р. професійно опрацьовані групою науковців бібліотеки на чолі з упорядником i автором вступної частини Ларисою Купчинською 3 грубезних томи Каталогу колекції С. Давимуки [8]. Заради справедливості варто зазначити, що каталоги своїх екслібрисних фондів також опрацьовували й опублікували Музей «Кобзаря» в Черкасах, Херсонський художній музей ім. О. О. Шовкуненка, Національна бібліотека України ім. В. І. Вернадського, наукова бібліотека Львівського національного університету ім. І. Я. Франка та Одеська національна наукова бібліотека ім. М. Горького.

Дослідження книжкового знаку краще вдаються колекціонерам на базі ї зібрань. Варто наголосити, що до уваги в цій статті бралися роботи художників, які систематично працюють у жанрі книжкового знаку й заявили про себе як на теренах України, так і за ії межами. Їхній здобуток у цій сфері налічується сотнями екслібрисів, наприклад, Анатолій Алексєєв 3 Чернігова створив 250 екслібрисів, Олексій Литвинов із Харкова - 330, Микола Неймеш із Харкова - 580, Георгій Сергєєв з Києва - 850, Давид Беккер з Одеси і В. Леоненко 3 Чернігова - понад тисячу кожен.

Мета статті - розкрити визначну роль екслібриса як нарису історії культури України, комплексу духовних здобутків суспільства.

Виклад основного матеріалу. Головною й домінуючою в екслібрисах була й залишається літературна тематика, адже це книжковий знак. Особливо популярною є творчість Пушкіна, Гоголя, Шевченка, великі цикли графічних мініатюр оспівували поезію С. Єсеніна, М. Рубцова, А. Ахматової, наших сучасників: I. Драча, Л. Костенко та інших. До ювілейних дат, і не тільки, митці творили численні екслібриси, присвячені «Слову о полку Ігоревім», «Русалці Дністровій», образам з творів Івана Франка, Лесі Українки. 
Особливою популярністю користувалась творчість легендарного поета, музиканта й актора Володимира Висоцького, у якого було чимало шанувальників. Вони замовляли екслібриси Миколі Бондаренку з Сумської області, Оресту Криворучку з Чернівців, Миколі Неймешу та Олексію Литвинову з Харкова. Останній на початку 1990-х рр. створив для Вадима Альбертіна 3 Очакова 2 десятки екслібрисів 3 образами В. Висоцького та героїв його творів. Це чорно-білі та кольорові композиції (в 2-3 кольори), в яких поет постає 3 неодмінною гітарою (чорно-біла плашка) й опиняється на тлі сюжетів своїх пісень, надрукованих у кольорі, у відповідному місці композиції. Глядач із задоволенням розгадує, до якої пісні створено певний сюжет. В одному з екслібрисів бард постає на тлі образу своєї музи - Марини Владі.

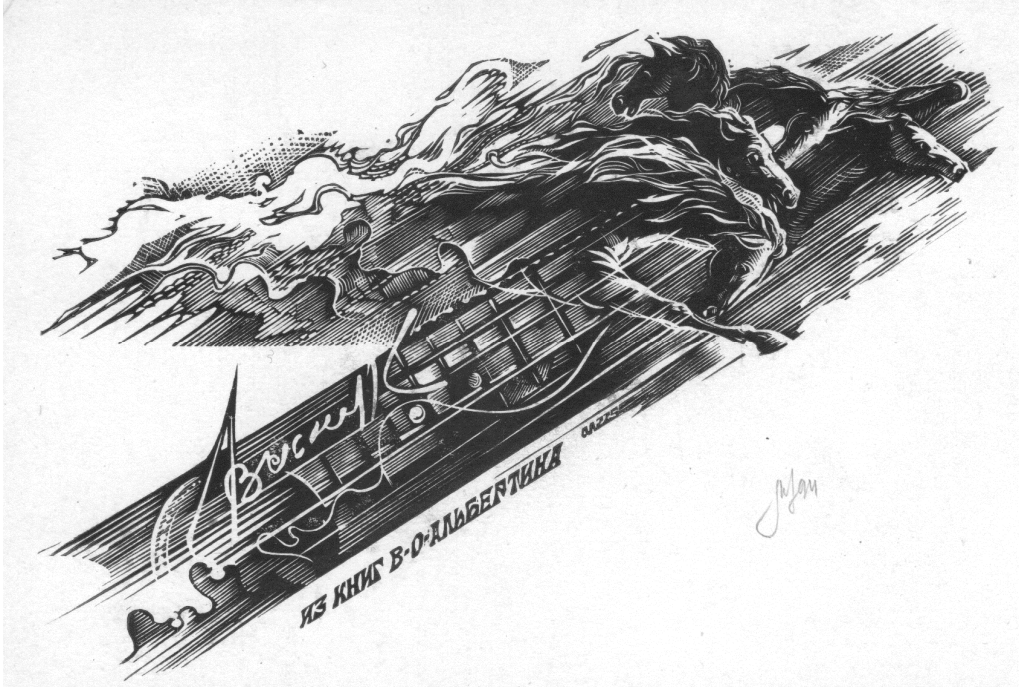

Рис. 1. Литвинов О. Екслібрис В. Альбертіна. Гравюра на пластику. $1994 \mathrm{p}$. 
Цікава особистість колекціонера, колишнього шкільного вчителя фізики 3 м. Очаків Миколаївської області Вадима Альбертіна (рис. 1). 40 років він збирав усе, що пов'язане 3 В. Висоцьким. Свої скарби колекціонер з успіхом експонував у рідному місті, в 2010 р., до 30-ти річчя 3 дня смерті В. Висоцького, в Центральній бібліотеці ім. М. Кропивницького в Миколаєві. На виставці біли представлені прижиттєві фотографії кумира, його платівки, раритетні книжки, журнали, публікації. Але основу зібрання В. Альбертіна складає унікальна колекція екслібрисів, яка нараховує понад 700 екземплярів, серед яких значна кількість адресована саме йому. Нині колекція зберігається в Миколаївській науково-педагогічній бібліотеці, цьому ii працівники завдячують директору миколаївського видавництва «Наваль» Леву Траспову. Його видавництво випустило в світ 2 книги, присвячені пам'яті поета й виконавця власних пісень, остання вийшла в 2008 р.

Не менш популярною в мистецтві екслібриса була Анна Ахматова (справжнє прізвище Горенко) (рис. 2).

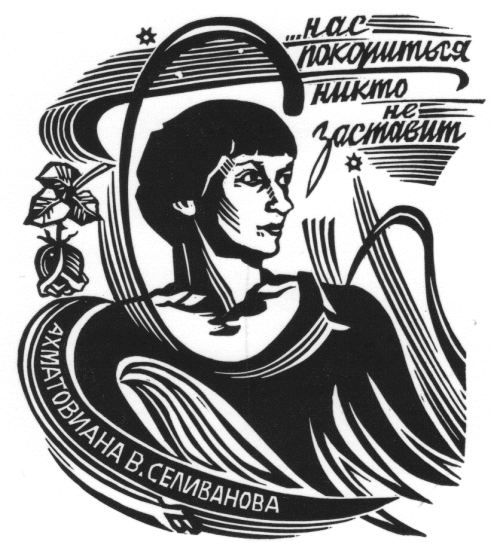

Рис. 2. Леоненко В. Екслібрис В. Селіванова. Лінорит 
Ïї поетичні рядки приваблювали мільйони людей як у нашій країні, так і за кордоном. Друкуватися Ахматова почала рано. Її перші твори побачили світ у 1911 р. Напередодні Різдва 1903 р. Анна познайомилася з Миколою Гумільовим. Тоді 14-річна Аня Горенко була стрункою дівчинкою з великими сірими очима, які різко виділялися на тлі блідого обличчя і прямого чорного волосся. Їі витончений профіль, що нагадував античні камеї, притягував увагу численних шанувальників. Проте велика поетеса не була принадна до ролі люблячої дружини, отож вона стала ідеальною вдовою. За часів сталінізму вона була приречена на «ходіння по муках».

...У 1951 p. Анну Ахматову поновили у Спілці радянських письменників й почали друкувати іiі твори. Ще за життя поетеси деякі художники дарували їй свої екслібриси. На прохання сучасника й шанувальника таланту Ахматової відомий російський бібліофіл і колекціонер Е. Ф. Голлербах замовив у майстра графіки Павла Шилінговського книжковий знак. На екслібрисі були гарно скомпоновані предмети з зображенням пам'ятника О. С. Пушкіну в Дитячо-сільському парку. Біля підніжжя пам'ятника розкриті книжки, сувої з іменами поетів XIX i XX ст. На одній із книг чітко видно напис: «Анна Ахматова», «Чотки». Екслібрис створений у 1925 р. - це перший знак низки численних знаків «Ахматовіани». Шанувальник поезії Ахматової київський художник К. С. Козловський (19051976 рр.) тричі у своїй творчості робив для поетеси екслібриси. У 1957 р. він виконав перший книжковий знак для опальної мисткині. У ньому розкрита книга 3 чорнильницею на тлі грозового неба зі зламаним деревом - це натяк на несприятливу атмосферу, в якій жила Ахматова.

Серед авторів екслібрисної «Ахматовіани» художники радянських республік, серед яких чимало українських шанувальників творчості поетеси 3 Києва, Львова, ІваноФранківська, Одеси, Чернівців. Видавець Володимир Селіванов з Одеси дослідив екслібрисну спадщину й видав 150-тисячним 
тиражем каталоги, в яких відтворено понад сотню екслібрисів. Це «Анна Ахматова в графике и экслибрисе к 125-летнему юбилею» і 2 випуски «Антологии ахматовского экслибриса» [1, 2, 3]. У більшості екслібрисів художники зображували характерний профіль молодої поетеси. Київський художник А. С. Мистецький (1910-1985 рр.) неодноразово звертався до образу Ахматової і згодом створив малотиражну добірку 3 14 екслібрисів під загальною назвою «Тут проживала А. А. Ахматова».

Значна кількість екслібрисів присвячена музиці й музикантам. Музика - це продукт, який сприймається слухом у режимі реального виконання. Справжній професіонал намагається передати те, що заклав у композицію іiі автор, а слухач, якщо це буде добре подано, зможе цю емоцію відчитати, в свою чергу, до глядача донесе музичне мистецтво мовою графіки художник. Автор понад тисячу екслібрисів Давид Беккер з Одеси - художник широкого діапазону тематики: біблійні сюжети, антична міфологія, архітектура, видатні особистості, літературні герої, вишукані жінки, еротика, тварини і ще багато чого. За свої екслібриси, створені у техніці кольорового офорту, він отримав чимало нагород у багатьох країнах світу. Д. Беккер взяв участь у десятках виставок в Україні та за кордоном, мав понад 60 персональних виставок. Свій перший екслібрис художник виконав у техніці ліногравюри в далекому 1968 році.

В Одесі у друкарні вже знайомого читачу Володимира Селіванова надруковано низку якісних кольрових каталогів екслібрисів різної тематики. Розглянемо зміст двох із них: «Звучащей музики штрихи» $\mathrm{i}$ «Венецианский карнавал. Графика» [4, 5]. У першому дуже якісно відтворено 35 мініатюрних кольорових композицій, адресованих переважно зарубіжним шанувальникам музики. В основі багатьох із них постає образ відомого композитора в оточенні героїв його творів. Це І. Бах, Ж. Бізе, А. Вівальді, В.-А. Моцарт, 
М. Мусоргський, М. Римський-Корсаков, П. Чайковський, Ф. Шуберт, та інші. На нотному стані (улюблений прийом художника) розташовуються й живуть герої творів Бетховена («Місячна соната»), Моцарта («Чарівна флейта»), Бізе («Кармен»), Верді, Пуччіні, Шуберта тощо. Екслібриси Д. Беккера вражають своєю глибиною, високою майстерністю й бездоганною проробкою найменших деталей.

Низка пастелей Д. Беккера з серії «Карнавали Венеції», а також екслібриси, були присвячені знаменитому святу, яке щорічно відбувається у Венеції - карнавалу. Венеція XVIII ст. була наймузичнішим містом континенту. Слово «консерваторія» в сучасному значенні з'явилось саме там. Раніше воно означало «монастирський притулок». Венеціанці перетворили притулки в закриті музичні школи 3 кращими в Свропі оркестрами й хорами, які складалися 3 вихованок. У таких консерваторіях працювали знамениті композитори: Вівальді, Порпора, Скарлатті, Галуппі. Місто було пронизане музикою й зачароване театром. Так само зачаровують нас i вишукані екслібриси Д. Беккера, які сповнені атмосферою святкової розкоші. Кокетливо одягнені напівоголені жінки, галантні кавалери розкошують у присутності музикантів. Венеціанський карнавал отримав нове життя у творчості Давида Беккера, завдяки якостям, які відповідають абсолютному відчуттю стилю й високій професійній майстерності у техніці кольорового офорту.

«Comediada» - така назва екслібриса народного артиста України Георгія Делієва, відомого актора, режисера, художника, музиканта й художнього керівника театру «Маски-шоу», який створила його землячка О. Вальчук. Делієва зображено в одязі блазня, який жонглює кубиками, що відтворюють вищезгадану назву екслібриса. Майстерно виконана кольорова гама екслібриса, створеного в техніці лінориту.

Блазні у різних проявах - одна 3 улюблених тем київських графіків Аркадія й Геннадія Пугачевських (батька й сина). В екслібрисах Геннадія блазня зображено за спиною 
короля у вигляді його тіні, сидячого на гральній картці короля пік, або граючого на трубі на тлі чорно-білої шахової дошки. Не менш цікаві екслібриси Аркадія. Його блазень всівся верхи на віслюка й тримає спрямоване на глядача дзеркало, яке відблискує сріблястою поверхнею й гарно доповнює кольорове зображення.

Для німецького колекціонера екслібрисів Ганса Іоахіма Паулуса Аркадій виконав багатокольоровий екслібрис на пластику, в якому зобразив героїв казки «Бременські музики», створеної братами Грімм у 1819 р. Скульптор Герхард Маркс у 1951 р. установив «піраміду» - музикантів, які стоять один на одному: осел, пес, кіт і півень. У цій самій послідовності зображено й героїв екслібриса Аркадієм Пугачевським, проте $є$ суттєві доповнення, враховуючи, що в 1998 р., коли творився книжковий знак, Німеччина переходила з дойчмарок на євро, отже, осел, за бажанням художника, поглинав марки й, пропустивши їх через шлунок, видавав уже «єврики». Всі тварини у художника наділені веселою вдачею, а кіт ще й грає на трубі та тримає парасольку. До речі, у 2007 р. у казковій скульптурі було встановлено «співаючий отвір», куди туристи вкидають монети і за вцей несок слухають знаменитий спів бременських музик.

Подібний сюжет став окрасою і екслібриса для Едвіна Смітса, створеного Володимиром Вишняком із Київської області. Його кольорова гравюра на пластику надрукована 3 6 дошок і зображує героїв братів Грімм, що завзято музикують. Художнику притаманне ліричне сприйняття світу, доброзичливе ставлення до героїв своїх книжкових знаків. Це спостерігається і в інших сюжетах: канатохідцем, що гуляє над площею європейського міста, чи веселих мисливців, які несуть спійманого вовка, за якими спостерігають Червона Шапочка та iіi бабуся.

У 4 дошки надруковано 666 екслібрис Василем Леоненком 3 Чернігова для Краківського театру імені 
Я. Словацького. У ньому на тлі театральної завіси зображено жовто-червоного збаня й 2 театральні маски, які символізують драму i комедію. На другому плані у світлі рампи постає театральне дійство. Чорно-білий екслібрис Ірини Колядіної адресований режисеру Дніпровського лялькового театру В. Барку. Незважаючи на відсутність бажаного кольору, він майстерно передає робочий процес, коли 3 лялькові маріонетки приводяться в рух за допомогою ниток актором-ляльководом, прихованим від глядача.

Майстри книжкового знаку полюбляють вшановувати видатних діячів культури і мистецтва минулого й присвячувати ім екслібриси пам'яті. Чимало таких графічних мініатюр створив Георгій Сергєєв із Києва. Вражає своїм пронизливим і водночас сумним поглядом екслібрис пам'яті режисера, актора, драматурга, народного артиста України Леся Курбаса (19871937 р.), адресований Лесю Танюку, в його виконанні. Ще трагічнішим виглядає екслібрис львів'янина Бориса Дроботюка, в якому Курбас постає як в'язень за гратами.

В іншому екслібрисі Г. Сергєєва - пам'яті народного артиста оперети України і Радянського Союзу з Одеського театру музичної комедії Михайла Водяного (1924-1987рр.), адресованого одеситу Володимиру Селіванову, актор постає в ролі улюбленця глядачів Попандопула. При роботі над цією роллю Водяний звернувся за допомогою до одеських стиляг, один 3 яких подарував актору свій одяг - екзотичну сорочку 3 пальмами, єгипетськими пірамідами, та яскраву краватку. Проте в екслібрисі Водяний постає у морському тільнику й екзотичному головному уборі.

Болюче пережив Сергєєв смерть всесвітньо відомого українського оперного співака, соліста Паризької національної опери, волонтера, учасника Революції Гідності та бойових дій на Сході, героя України Василя Сліпака (1974-2016 рр.). Його брату, Оресту, він присвятив екслібрис пам'яті героя, який усе покинув для захисту України. 
Вшанували художники й Заслуженого артиста України Івана Миколайчука (1941-1987 pp.), якого недаремно називають обличчям і душею українського поетичного кіно, аристократом духу, самородком, кінозіркою 1960-70-х рр. У ті роки майже жоден фільм не обходився без його участі. 34 ролі в кіно, 9 сценаріїв та 2 режисерські роботи в активі легенди не лише національного, а й світового кінематографу. Він був справжній, найкращий, в його особі українська нація має позитивного героя, який пробуджував національний дух. 3 екслібриси пам'яті Івана Миколайчука створив у 2010 і 2011 рр. його земляк Іван Балан із Чернівців. У кожному 3 них присутній «білий птах 3 чорною ознакою». Блискуча акторська гра Миколайчука в однойменному фільмі Юрія Іллєнка була високо оцінена на міжнародних фестивалях у Москві та Сорренто. Ще 2 екслібриси $з$ портретами кінозірки адресовані актору вже після його смерті, у 1990 i 2012 pp., Ярославом Омеляном iз Тернополя і Мирославою Шевченко з Києва.

Значну кількість екслібрисів присвятив акторам Заслужений художник України Іван Крислач зі Львова (19292017 рр.). Значна частина 3 них відтворена у третьому малоформатному виданні, здійсненому коштом автора: «Екслібрис Івана Крислача» [6]. Серед них оперний співак, народний артист України Степан Степан (1938-2017 рp.) соліст Львівської національної опери ім. С. Крушельницької. В його репертуарі понад 100 арій, народних пісень, щедрівок, колядок. Виконавець партії Набукко в однойменній опері Верді, отамана - в опері «Тарас Бульба» Лисенка, султана - в «Запорожці за Дунаєм» Гулака-Артемовського та багатьох інших. В екслібрисі (2006 р.) І. Крислач зобразив його у вигляді молодого красеня поруч із кокетливою жінкою. Інший екслібрис художника присвячений оперній співачці, Народній артистці України Володимирі Чайці (1928-2015рр.). Вона виконувала партії Оксани 3 опери «Запорожець за Дунаєм» Гулака-Артемовського, Віолетти, Джильди («Травіата», 
«Ріголетто» Верді), Констанци («Викрадення 3 сералю» Моцарта), Лейли («Шукачі перлин» Бізе) та ін. В екслібрис (2008 р.) артистка зображена у вигляді молодої жінки у профіль i 3 віялом на тлі Львівської національної опери. Актор Львівського театру ім. М. Заньковецької, Народний артист України Святослав Максимчук особливу популярність здобув як майстер художнього читання. Йому притаманні унікальна пам'ять, тонке відчуття стилю Івана Франка, глибоке прийняття психологією його творів. Саме в образі Мойсея, який титанічними зусиллями тримає, ніби скелі, гігантські скрижалі, зобразив його Крислач в екслібрисі 2004 р. Угорі рядки 3 прологу поеми «Мойсей», «Народе мій...» та багато інших.

Чимало екслібрисів виконали художники для музеїв. Для львівських музеїв значну кількість створив і І. Крислач: Івана Франка (1980р.), Івана Федорова (1981р.), Музею-садиби Маркіяна Шашкевича (1986 р.), Музею етнографії АН України (1999 р.), Олени Кульчицької (2003 р.), Національного музею у Львові (2004 р.), Соломії Крушельницької у Львові (2007 р.), Львівської галереї мистецтв (2007р.) та інших установ культури. У 1991 р. І. Крислач взяв участь у міжнародному конкурсі на кращий екслібрис для наукової бібліотеки КиєвоМогилянської академії та переміг. У творі зображені студент із розкритою книгою академії й козак, які шанобливо вклонилися на тлі академічної споруди. Їх благословляє Божа Матір Покрова, а вгорі - дати, 1615-1992 pp.

Образи знаменитих діячів культури минулого постають в екслібрисах видатного майстра графіки малих форм Василя Леоненка 3 Чернігова. Польським шанувальникам творчості Фредеріка Шопена присвячені його композиції 3 профілем композитора на тлі нотного ряду. Демонічний профіль знаменитого скрипаля й композитора Нікколо Паганіні постає в екслібрисі «Ex musicis Tadeusha Ortyla» (опус 924, 1999 р.). Грайливі графічні контури, які віддалено нагадують форми скрипки, органічно доповнюють образ Паганіні. Художнику 
досить використати у своїх ліноритах всього два кольори щоб надати їм особливої поезії й мажорного звучання.

Висновки. Представлені досягнення майстрів екслібриса свідчать про їхню високу громадянську позицію, яка включає пошук i створення вивірених, продуманих композицій, вишукане графічне зображення образу та емоційне втілення в кольорі. Замовляючи численним художникам екслібриси, колекціонери й шанувальники прекрасного надають символузнаку високого ідейного змісту, спонукаючи їх до нової форми художнього вислову.

\section{Література}

1. Анна Ахматова в графике и экслибрисе к 125-летнему юбилею. Одесса: Издание В. Селиванова, 2014. 17 с.

2. Антология ахматовского экслибриса. Одесса: Издание В. Селиванова, 2014. 19 с.

3. Антология ахматовского экслибриса. Вып. 2. Одесса: Издание В. Селиванова, 2016. 15 с.

4. Давид Беккер: Звучащей музики штрихи. Одесса, 2010,10 с.

5. Давид Беккер: Венецианский карнавал. Графика. Одесса, 2014, 10 c.

6. Екслібрис Івана Крислача / вступ. слово Р. Яціва. Львів, 2009.

7. Нестеренко П. Утвердження національного характеру основа художньої сутності українського книжкового знаку // Дзвін. Львів. 2018. № 5. С. 163-167.

8. Український книжковий знак XIX-XX століть : каталог колекції Степана Давимуки : у 3 т. / упоряд. і авт. вступ. частини Л. Купчинська; наук. ред. Л. Снісарчук. Львів: Апріорі, 2017. 


\section{Петр Владимирович Нестеренко,}

кандидат искусствоведения, доцент,

Национальная академия

изобразительного искусства и архитектуры,

Киев, Украина,

e-mail: exlibrisclub@ukr.net,

ORCID 0000-0003-4153-4175

\section{ЭКСЛИБРИС КАК ОЧЕРК ИСТОРИИ КУЛЬТУРЫ УКРАИНЫ, КОМПЛЕКСА ДУХОВНЫХ ИЗЫСКАНИЙ ОБЩЕСТВА}

Аннотация. Экслибрис, или книжный знак, исполняется художниками для своих друзей и знакомых, чаще бесплатно, а также для участия в международных или местных конкурсах, к памятным или юбилейным датам, а также на заказ, большей частью для иностранных коллекционеров. Таким образом, экслибрис является важным источником истории и культуры не только Украины, но и всего человечества.

Особенной популярностью пользовалось творчество легендарного поэта, музыканта и актера Владимира Высоцкого, у которого много почитателей. Они заказывали экслибрисы Николаю Бондаренко из Сумской области, Оресту Криворучко из Черновцов, Николаю Неймешу и Алексею Литвинову из Харькова. Последний создал для Вадима Альбертина 2 десятка экслибрисов с образом В. Высоцкого и героев его произведений.

Не менее популярной в искусстве экслибриса была Анна Ахматова. Ее поэтические строки привлекали миллионы людей на протяжении последних десятилетий, как в нашей стране, так и за рубежом.

Автор более 1000 экслибрисов Давид Беккер из Одессы - художник широкого тематического диапазона. Его творчество презентовано портретными образами известных композиторов и серией «Карнавалы Венеции». 
Не мене интересны цветные экслибрисы Аркадия и Геннадия (отца и сына) Пугачевских, Владимира Вишняка из Киева, Василия Леоненко из Чернигова и других.

Мастера книжного знака любят чествовать выдающихся деятелей культуры и искусства прошлого и посвящать им экслибрисы памяти. Много таких графических миниатюр создали Георгий Сергеев из Киева, Борис Дроботюк из Львова, Иван Балан из Черновцов и другие.

Экслибрисы Заслуженного художника Украины Ивана Крислача из Львова посвящены солистам Львовской национальной оперы им. С. Крушельницкой и актерам Львовского театра им. М. Заньковецкой. Он также является автором многочисленных книжных знаков для львовских музеев.

Ключевые слова: экслибрис, художник, конкурсы, юбилейные даты, культура, театр, музей, коллекционеры, поэты, музыканты, композиторы, актеры

\section{Petro V. Nesterenko,}

$\mathrm{PhD}$ in Arts, Associate Professor,

National Academy of Fine Arts and Architecture, Kyiv, Ukraine, e-mail: exlibrisclub@ukr.net, ORCID 0000-0003-4153-4175

\section{EX-LIBRIS AS AN ESSAY ON THE HISTORY OF UKRAINIAN CULTURE, A COMPLEX OF SPIRITUAL ACHIEVEMENTS OF SOCIETY}

Abstract. An ex-libris, or book plate, is work, created by artists for their friends and acquaintances, often free of charge, as well as for participation in international or local competitions, for anniversaries, and to order, mostly by wealthy foreign collectors. 
Thus, the ex-libris is an important source of history not only of Ukrainian culture, but of all mankind.

The creativework of the legendary poet, musician and actor Volodymyr Vysotsky, who had many fans, was especially popular. They ordered bookplates from Mykola Bondarenko from Sumy region, Orest Kryvoruchko from Chernivtsi, Mykola Neimesh and Oleksiy Litvinov from Kharkiv, who created 20 bookplates with the image of V. Vysotsky and the heroes of his works for Vadim Albertin from Ochakov in the early 1990s.

Anna Akhmatova was no less popular in the art of ex-libris. Her poetic lines have attracted millions of people, both in our country and abroad. The author of more than a 1000 ex-libris David Becker from Odessa is an artist of a wide range of subjects. His work is presented with portrait images of famous composers and a series of "Carnivals of Venice".

The color ex-libris of Arkady and Gennady (father and son) Pugachevsky, Volodymyr Vyshnyak from Kyiv, Vasyl Leonenko from Chernihiv and others are no less interesting.

Masters of the book plate like to honor outstanding figures of culture and art of the past and dedicate EL of memory to them. Many such graphic miniatures were created by Georgy Sergeyev from Kyiv, Borys Drobotyuk from Lviv, Ivan Balan from Chernivtsi and others.

Ex-libris by the Honored Artist of Ukraine Ivan Kryslach from Lviv are dedicated to the soloists of the S. Krushelnytska Lviv National Opera and actors of M. Zankovetska Lviv Theater. He is also the author of numerous book plates for Lviv museums.

Key words: ex-libris, artist, competitions, anniversaries, culture, theater, museum, collectors, poets, musicians, composers

\section{References}

1. Anna Ahmatova $\mathrm{v}$ grafike i ekslibrise $\mathrm{k}$ 125-letnemu yubileyu (2014) [Anna Akhmatova in graphics and book plates for the 125th anniversary, Odessa [in Russian]. 
2. Antologiya ahmatovskogo ekslibrisa (2014) [Anthology of Akhmatova book plate]. Odessa [in Russian].

3. Antologiya ahmatovskogo ekslibrisa (2016) [Anthology of Akhmatova book plate], 2. Odessa [in Russian].

4. David Bekker (2010): Zvuchaschey muziki shtrihi [David Becker: Streakes of playing of music], Odessa [in Russian].

5. David Bekker: Venetsianskiy karnaval: Grafika (2014) [David Becker: Venetian Carnival: Graphics]. Odessa [in Russian].

6. Ekslibrys Ivana Kryslacha (2009) [Book-plates of Ivan Kryslach]. Vstup. slovo R. Yatsiva. Lviv [in Ukrainian].

7. Nesterenko, P. (2018). Utverdzhennia natsionalnoho kharakteru - osnova khudozhnoi sutnosti ukrainskoho knyzhkovoho znaku [Consolidation of national character - the basis of the artistic nature of Ukrainian book plate]. Dzvin. Lviv, 5, 163- 167 [in Ukrainian].

8. Ukrainskyi knyzhkovyi znak XIX-XX stolit': kataloh kolektsii Stepana Davymuky (2017). [Ukrainian book plate of XIXXX centuries: catalog of Stepan Davymuka's collection]: u 3 t. Uporiad. i avt. vstup. chastyny L. Kupchynska; nauk. red. L. Snisarchuk, Lviv: Apriori [in Ukrainian]. 